\title{
Eurosodom: Specifics of Weaponized Sexuality and Gender-Based Narratives in Contemporary Russian and Pro-Russian Disinformation
}

Eurosodom: aspectos especificos de la sexualidad armada y las narrativas basadas en el género en la desinformación rusa y prorrusa contemporánea

Eurosodom: especificidades da sexualidade armada $e$ narrativas de gênero na desinformação russa contemporânea e pró-russa

Ellery G Cushman, M.G.P.S, M.A.

The LBJ School of Public Affairs

(The University of Texas at Austin)

https://orcid.org/0000-0002-3019-2109

United States

\section{Kiril Avramov}

Assistant Professor

Department of Slavic and Eurasian Studies

Fellow to the Intelligence Studies Project at The LBJ School of Public Affairs

(The University of Texas at Austin)

https://orcid.org/0000-0001-7426-9166

United States

Reception date: 13 September 2020

Review date: 14 September 2020

Accepted date: 4 December 2020

Published: 1 January 2021

To cite this article: Cushman, E. G. \& Avramov, K. (2021). Eurosodom: Specifics of Wea-

ponized Sexuality and Gender-Based Narratives in Contemporary Russian and Pro-Russian

Disinformation, Icono 14, 19(1), 123-154. doi: 10.7195/ri14.v19i1.1626 


\section{Abstract}

The Kremlin, under the leadership of President Vladimir Putin, has sponsored a resurgence of political warfare against Western targets. This analysis will focus on a particular aspect of Kremlin-sponsored political warfare: sexuality and gender-based narratives in Russian and pro-Russian disinformation campaigns targeting EU and EU aspiring members from 2015-2020. The potency of these narratives arises from the emotional and cognitive load that they elicit. Their significance is often overlooked in security, intelligence, and communication studies. In order to alleviate this gap, this article consists of a mixed-methods investigation in order to analyze the role and function of these narratives within the larger body of Russian disinformation. This research shows that sexuality and gender-based disinformation narratives are designed to target basic human emotions, such as fear, anger, hostility, confusion, and disgust, by exploiting existing cognitive biases within the targeted population. These narratives are a useful and effective political and propaganda tool meant to elicit support for a specific brand of traditional values that furthers the Kremlin's geopolitical aim of creating an alternative to Western liberal hegemony.

Key Words: Russian disinformation; Narratives; Metanarratives; Sexuality; Gender

\section{Resumen}

El Kremlin, bajo el liderazgo del presidente Vladimir Putin, ha patrocinado un resurgimiento de la guerra política contra objetivos occidentales. Este análisis se centrará en un aspecto particular de la guerra política patrocinada por el Kremlin: la sexualidad y las narrativas basadas en el género en las campañas de desinformación rusas y prorrusas dirigidas a la UE y a los aspirantes a miembros de 2015-2020. La potencia de estas narrativas surge de la carga emocional y cognitiva que provocan. Su importancia a menudo se pasa por alto en los estudios de seguridad, inteligencia y comunicación. Para aliviar esta brecha, este artículo consiste en un análisis de métodos mixtos para analizar el papel y la función de estas narrativas dentro del cuerpo más amplio de la desinformación rusa. Esta investigación muestra que las narrativas de desinformación basadas en la sexualidad y el género están diseñadas para apuntar a las emociones humanas básicas, como el miedo, la ira, la hostilidad, la confusión y el disgusto, explotando los sesgos cognitivos existentes dentro de la 
Eurosodom: Specifics of Weaponized Sexuality and Gender-Based Narratives... | 125

MONOGRAPH

población objetivo. Estas narrativas son una herramienta politica y de propaganda útil y eficaz destinada a obtener apoyo para una marca específica de valores tradicionales que promueve el objetivo geopolítico del Kremlin de crear una alternativa a la hegemonía liberal occidental.

Palabras clave: Desinformación rusa; Narrativa; Metanarrativas; Sexualidad; Genero

\section{Resumo}

0 Kremlin, sob a liderança do presidente Vladimir Putin, patrocinou o ressurgimento da guerra política contra alvos ocidentais. Esta análise se concentrará em um aspecto particular da guerra politica patrocinada pelo Kremlin: sexualidade e narrativas baseadas em gênero nas campanhas de desinformação russas e pró-russas direcionadas à UE e membros aspirantes de 2015-2020. A potência dessas narrativas decorre da carga emocional e cognitiva que elas provocam. Seu significado é frequentemente esquecido em estudos de segurança, inteligência e comunicação. Para aliviar essa lacuna, este artigo consiste em uma análise de métodos mistos para analisar o papel e a função dessas narrativas dentro do corpo mais amplo da desinformação russa. Esta pesquisa mostra que as narrativas de desinformação baseadas em sexualidade e gênero são projetadas para atingir emoções humanas básicas, como medo, raiva, hostilidade, confusão e repulsa, explorando os preconceitos cognitivos existentes na população-alvo. Essas narrativas são uma ferramenta política e de propaganda útil e eficaz destinada a obter apoio para um tipo específico de valores tradicionais que promovem o objetivo geopolítico do Kremlin de criar uma alternativa à hegemonia liberal ocidental.

Palavras chave: Desinformação russa; Narrativa; Metanarrativas; Sexualidade; Gênero

\section{Introduction}

Policymakers and academics in the United States have focused almost exclusively on one factor of Kremlin-sponsored political warfare: Russian interference in the 2016 American Presidential Election. However, Europe, and in particular the European Union and its aspiring members, has been the perennial target for 
the Kremlin in the post-Soviet era (McCauley, 2016). This analysis will focus on a particular aspect of Kremlin-sponsored political warfare in Europe: Russian and pro-Russian sponsored disinformation campaigns targeting various European populations. Disinformation is specifically tailored for each target, manipulating, distorting, dismissing, or fabricating locally relevant information to substantiate broader metanarratives that support Russian foreign policy interests. Russian and pro-Russian disinformation has become a popular topic in the news and academ$\mathrm{ia}$, and scholars have focused on several elements of disinformation ranging from the role of advertising, to the technology used to disseminate false stories, to the motivations of threat actors, to the narrative content of disinformation. This analysis will consist of a content analysis of sexuality and gender-based narratives in Russian disinformation from a set time period and database.

In this article we survey the narrative landscape of Russian disinformation in Europe from 2015 to present based on a disinformation database managed by the European External Action Service. This database, EU vs. Disinfo, is "the only searchable, open source repository of its kind-which currently comprises over 8,800 samples of pro-Kremlin disinformation" in 31 languages (EU vs. Disinfo, 2020). In scrutinizing this larger body of disinformation, an interesting trend emerged of false stories built on sexuality and gender-based narratives targeting the West. These stories are highly reminiscent of classic atrocity propaganda that has characterized political and psychological warfare for centuries. Thus, our analysis focuses specifically on those pieces of disinformation characterized by sexuality and gender-based narratives. In order to analyze these narratives, we conduct a mixed-methods analysis of this topic from this particular subsample, relying on the frameworks of rumor theory and narrative theories, while focusing on the following research questions:

- What are the most commonly utilized sexuality and gender-based narratives in Russian and pro-Russian disinformation campaigns?

- What is the role and function of these narratives within the larger body of Russian and pro-Russian disinformation from 2015-2020? 
Eurosodom: Specifics of Weaponized Sexuality and Gender-Based Narratives... | 127

MONOGRAPH

We understand "weaponized" sexuality and gender-based narratives as resembling classic atrocity propaganda, intended to exploit existing cognitive biases and create efficient cognitive shortcuts that can elicit desired behavioral or cognitive change in the targeted population (Kahneman, 2011). Based on this understanding, we propose a working hypothesis on the role and function of these kinds of disinformation narratives.

Namely, the intent of the utilization of these narratives within the larger body of disinformation is to sow confusion, elicit disgust and incite moral panics in the targeted populations (Avramov \& Cushman, 2019). Sexuality and gender-based narratives are not unlike other forms of disinformation in this way; their emotional load is so intense that the target population is often overwhelmed with strong emotion, as mentioned above, which can lead to the classic " $4 \mathrm{D}$ " effect of disinformation: dismiss, distort, distract, dismay (Gourley, 2020). However, we hypothesize that sexuality and gender-based narratives serve Kremlin interests in another significant way. These narratives are employed to support broader geopolitical aims of the Russian Federation, namely increased distrust in the ideas of multiculturalism, tolerance, feminism, and liberalism expressed through an overall Eurosceptic worldview. Furthermore, these narratives are intended to promote a real political and cultural alternative to Western liberal democracy that is modeled after Putin's Russia through the use of traditional imaginings of masculinity and femininity, the family unit, and other conservative Christian imagery.

In addition, stories that are characterized by sexuality and gender-based narratives are not random but conform to a common storyline pattern. They can typically be distilled down to one storyline with a perennial cast of characters that is easily recycled and adapted over time. This storyline is replete with dual imagery and binary oppositions that seem to be contradictory, but that actually represent broad narratives that support one another. In this analysis, these broad narratives will be referred to as "metanarratives", which are cross-cultural narrative systems that frequently reappear over long stretches of time, providing an explanatory framework that can be applied to a population's interpretation of information (Bernardi, et al, 2012). In this analysis, seven metanarratives were detected that warrant further scrutiny. These metanarratives are meant to elicit emotional and 
cognitive support for Russian foreign policy and security objectives, while undermining the perception and image of the "liberal West". When combined, these images paint a complete picture: the West is a decaying power, a kind of 'Eurosodom' that has become a bastion of material decadence and moral deviance, which is now at the mercy of a resurgent Russia that is destined to rise up from historical tragedy to be the savior of "true Christian European" civilization. Also central to this analysis is an understanding of the cultural and historical foundations that support the Kremlin's use of "othering" discourse in their contemporary information and influence operations. These '0thers' are remnants of an Imperial and Soviet past, frameworks of discrimination against Jews and Muslims and an idea of a conspiring West that inform the Kremlin's political rhetoric today. However, unlike in the past, the Kremlin today is predominantly relying on gender discourse and a scapegoating of LGBTQ+ populations in tandem with these older forms of othering to legitimize and reinforce the rule of President Vladimir Putin.

\subsection{Gender and Masculinities in Contemporary Russia}

Gender is a crucial element of the social order. Ideas of masculinity and femininity overlay all aspects of public and private life and organize ideas of nation, class, and culture (Cohn, 1993). As Riabova and Riabov (2019) state, gender discourse has "broader relevance and significance beyond the scope of sexual relations, because [gender] contributes to maintaining the collective identity, establishing social inequality, and providing political mobilization." The gendered political performance of political leaders such as Vladimir Putin, Recep T. Erdogan, and Jair Bolsonaro has attracted recent scholarly attention pointing out that reliance on gendered discourses and paternalist metaphors is increasingly common in right-wing populist parties worldwide (Eksi \& Wood, 2019). In this regard, the relationship between gender and right-wing populism is central to understanding the ways that male populist leaders posture themselves both domestically and on the international stage.

As critical discourse analyst Teun A. Van Dijk has shown, "ideologies seldom express themselves directly in text and talk; rather, they work indirectly, often concealing both their origins and effects" (Van Dijk, 1995). As Eksi and Wood (2019) 
Eurosodom: Specifics of Weaponized Sexuality and Gender-Based Narratives... | 129

MONOGRAPH

argue, it is likely no accident that so many right-wing politicians engage in masculine, "macho," and strongman approaches in their public discourse and actions, while describing these behaviors as "political masculinities" - "the conscious or unconscious (often semi-conscious) performance of masculine stereotypes by individuals operating within the political sphere. Right-wing populist political masculinities are distinct from other displays of masculinity in the political sphere because of their explicit goal of undermining democratic infrastructures. Thus, we agree with the argument that these masculine performances can be "designed to create spectacle" in order to distract the populace from serious economic problems. However, these performances are often central to the legitimacy of right-wing populist leaders, where a cult of masculinity is built at the top of the power structure which creates a necessity for a strong, sometimes openly aggressive, masculine leader.

Since Vladimir Putin's return to the presidency in 2012, scholars have recognized a "remasculinization" of Russian domestic politics and in the state's international posturing and version of national security (Riabov \& Riabova, 2014). The ideas of gender and nationalism are often utilized in "legitimizing the transition from one social system to another," and gender discourse has long played a significant role in the way that the Russian state and leadership construct national identity. In the specific case of President Vladimir Putin, gender discourse and masculine imagery has served as an explicit strategy of the Kremlin to legitimize both Putin and his regime as a defender of the Russian state and people, living inside and outside Russia (Yablokov, 2018). The images of Putin are well known around the world: shirtless on a horse, surrounded by women declaring their love for him, shooting guns and hunting, and partaking in a plethora of athletic events. Vladimir Putin has effectively created what Eksi and Wood (2019) describe as "Janus-faced masculinity," where he is an "outsider-yet-insider and a bad-boy-yet-good-father." Putin is simultaneously an everyman and unlike any other man. His form of masculinity is not just one of heightened superficial machismo performances, but a more diverse repertoire of behaviors that combine bullying, masculinity, paternalism, and deeply conservative messaging. Putin's image has been carefully crafted to portray him as both overly aggressive abroad and paternalistic and protective of the Russian people. 


\section{MONOGRAPH}

Scholars such as Riabov and Riabova (2014) and Sperling (2015) argue that the "re-masculinization of Russia" is central to Putin's political legitimacy and is largely the reason that Kremlin, and Putin himself, have remained popular with domestic audiences. In contrast, Novitskaya (2017) argues that his specific brand of political masculinity is a reflection of "deeper anxieties and vulnerabilities that result in political overcompensation." This research assumes that both of these understandings can be true at once. Clearly, Putin has crafted his image and masculine performance as a legitimization strategy since returning to power for the second time. This kind of legitimization tactic is not unique to Russia, but is in fact a widespread, universal phenomenon: the use and abuse of the power of gender norms and sexualization as a means of political legitimation. In this way, "the cultural framing of masculinity under patriarchy makes the assertion of masculinity a vehicle for power," thereby enabling male political leaders to "assert their power over others who can be identified or characterized as traditionally feminine" (Sperling, 2015). This allows traditionally masculine leaders to rely on gender discourse and norms, including "machismo, homophobia, and gay-baiting," as a way to delegitimize their political adversaries, both domestic and foreign (Sperling, 2015). This strategy has been central to Putin's domestic positioning, which relies on a traditional binary of masculinity and femininity, in which each sex has specific and distinct roles and non-heterosexual individuals are marginalized if not nonexistent in Russian society. Putin has effectively combined gender discourse, as thinly veiled xenophobia, with nationalism to embolden the latent populist sentiments in the general population against out-groups that do not fit into the new national identity. Putin often makes broad pronouncements about the "real Russians" who are depicted as brave and masculine, contrasting them with those who are cowardly and emasculated (i.e. feminine or semi-feminine) (Eksi \& Wood, 2019). Sexual and gender minorities in particular have become an outgroup that the Kremlin depicts as foreign, as not emerging from Russia, but as being corrupted by the West as a way to weaken Russia from within. This allows the Kremlin to not just discriminate against sexual and gender minorities, but to depict them as a threat to national security. The clearest internal example in this regard would be the adoption in 2013 of the so-called 'gay propaganda' law in 2013, which bans "propaganda of nontraditional sexual relations" in the presence of minors - "a reference universally understood to mean a ban on providing children with access to 
information about the lives of LGBT people" (RFE/RL, 2018). Masha Gessen (2013) argues that Putin relies on non-heterosexual individuals to mobilize against in order to legitimize his own heavy hand. Similarly, Harvey Fierstein (2013) describes this as a scapegoating strategy of "making-you-visible-so-we-could-hate-you," and argues that Russian leadership's attack on non-heterosexual citizens is an attempt to distract and divide the citizenry's attention from the real problems of corruption and economic woes. Most importantly, Putin's attack on sexual and gender minorities as a distinctly Western phenomenon allows the Kremlin to create an image of a constant enemy conspiring to undermine the country. As a result, the Kremlin has described most democratic opposition groups in the entire post-Soviet space as being feminine, gay, and funded by the West (Novitskaya, 2017). Putin's performative masculinity has transformed Russian foreign policy in recent years, as Russia's foreign policy is increasingly categorized as 'masculine' or 'aggressive.' This has especially been the case when considering Russia's posturing towards NATO and the Ukraine crisis (Cheskin, 2017). This strategy has allowed the Kremlin to weaponize gender norms as a way to weaken the legitimacy of the West in the eyes of both Russian domestic audiences and foreign audiences that believe in a return to a traditional gender and family order. In Ukraine, for example, gender discourse has encouraged the integration of the "true Slavic family," juxtaposing it with the immoral practices of Europe (Cheskin, 2017). At the same time, Putin's overreliance on so-called Western 'gender ideologies' can be understood as a reflection of his own anxiety and insecurity on the international stage as he attempts to rebuild Russia to the global power that the Soviet Union was.

\subsection{Rumor theory application}

Rumors are a collective effort on behalf of a group or a subgroup to make sense of or explain some uncertain or ambiguous event with limited information. As we treat our disinformation samples as a type closely resembling rumors, we treat rumors as "unverified and instrumentally relevant information statements in circulation that arise in contexts of ambiguity, anger, or potential threat and that function to help people make sense and manage risk" (Di Fonzo, Bordia, 2007). This definition focuses on the contexts in which rumors flourish and the content of rumor statements. According to most basic rumor theory (e.g. Bordia and DiFonzo, 2009), there are 


\section{MONOGRAPH}

three core motivations that drive people to rumor discussions: 1) rumors allow people to cope with uncertain and threatening circumstances; 2) rumors allow people to build relationships with others in their group; and 3) rumors can assist in self-enhancement, creative positive emotions in individuals or groups about themselves (Fine, Heath, Eds., 2009). In this view, rumors arise when there is an information gap or ambiguity where the meaning or significance of an event is unclear. In this regard, we agree with Shibutani's statement that when "formal information is absent, people compensate by informally interpreting the situation," in order to fulfill a basic human core motivation: to make sense and understand (Shibutani, 1966).

Much of the traditional literature on rumor dissemination has focused on the "fact-finding motivation" that stems from uncertainty or ambiguity. This traditional research on rumors neglects an important subtype of rumors: those that are meant to increase social uncertainty. These kinds of rumors are especially common in the disinformation cases found in our sample of pro-Kremlin and Kremlin-sponsored disinformation. Often, these rumors are designed to induce confusion or chaos, and are often characterized by sexual violence, cultural decay, and are closely associated with other fear-based narratives. Furthermore, traditional definitions of rumor put natural community transmission at the center, defining rumor most often as a natural phenomenon that occurs when people are searching for answers among ambiguity. In contrast, disinformation is often the purposeful implantation of rumor into a population. This means that not all rumors are natural and spontaneous in their creation. However, the conventional definitions of rumor and rumor theory are still applicable to rumors created by propagandists because planted information is still tailored on a local level and disinformation spreads in a similar way to rumors: through information cascades (Sunstein, 2002).

Also significant to our analysis is the "crisis rumor" type, which is endemic in situations in which there is a dearth of or ambiguity about information about an important topic (Di Fonzo, Bordia, 2007). The Kremlin's propaganda machine aims to create a sense of constant crisis among both foreign and domestic populations, creating in effect a culture ripe for crisis rumors that can be exploited for political gain. Timothy Snyder coins this as a "politics of eternity," where Russian leadership has placed the country at the "center of a circle of eternal victimhood" 
Eurosodom: Specifics of Weaponized Sexuality and Gender-Based Narratives... | 133

through a "continuous sense of crisis." (Snyder, 2018). This kind of identity of crisis is often associated with conspiratorial thinking, as conspiracy theories are often an integral feature of disinformation campaigns. In our view, conspiracy theories are a larger construction, with detailed, fabricated plans, rather than a oneoff, singular false news story. Conspiracy theories are integral to understanding global populist movements and populist leaders on the far-right, as contemporary movements in the West are increasingly aligned with and find support from the Kremlin. The Russian state has a long history of exploiting conspiratorial thinking as a political tool, and Putin's Russia is no exception. As Ilya Yablokov (2018) argues in Fortress Russia, "two hundred years of conspiracy mythmaking have been decisive in shaping the notion that the West is the ultimate Enemy." Hence, the emergence and proliferation of anti-Western attitudes in the Post-Soviet Era have a solid and well-developed foundation. The notion of the collective West as a "conspiring other" has been instrumental in Russian state-making since the mid-2000s, and the gender-discourse emerging from the Kremlin has been a key feature of the Kremlin's attempt to legitimize heavy-handed rule and substantiate the idea of "sovereign democracy". Defined by Vladislav Surkov, "sovereign democracy" became one of the central "discursive instruments invented by the Kremlin to insulate Russia from democratization and to facilitate an authoritarian backlash in the 2000s" (Yablokov, 2018). However, the conception of the idea of 'sovereign democracy' also came to depend on the Kremlin's creation and weaponization of 'gender ideology,' especially as Putin's administration has begun to increasingly emphasize Russia's role as the protector of 'traditional values', family, and Christianity. Of course, "the tendency to define a country's place in the contemporary world by counter-posing gender norms" is not unique to Russia; however, Putin's Russia has become known for the promotion of a "particularly sexualized form of nationalism" in which Russian leadership has "used a norms- and values-based argument" to frame the imposition of foreign 'gender ideologies' into the country by conspiring others (Foxall, 2013; Sperling, 2015).

\section{Material and method}

Our analysis is primarily conducted through a narrative discourse lens, utilizing the framework set out in Narrative Landmines: Rumors, Islamic Extremism, and the 


\section{MONOGRAPH}

Struggle for Strategic Influence, by Bernardi et al. (2012). By utilizing narrative theory, each publication that is marred by disinformation can be treated as "micro-story" that can be sorted into "rumor families" and "rumor mosaics." Rumor families are clusters of disinformation micro-stories that share a common subject or focus and can be traced to a common antecedent." Rumors mosaics are clusters of "complementary" pieces of disinformation that "collectively and collaboratively reinforce a common narrative" (Bernardi, et al., 2012). Some aspects of rumor mosaics may explicitly or implicitly vertically integrate with common metanarratives. This vertical integration, defined as "vertical narrative coherence," "rests largely on the ability to link narratives across a vertical spectrum from the cultural eschatological at the top to the local or individual at the bottom" (Betz, 2008). The "quality and persuasiveness" of a disinformation micro-story "inheres from being able to logically connect" through a series of narratives vertically (Betz, 2008). These vertically aligned narratives then produce a metanarrative, which is formed of deeply embedded broad 'truths' that typify a set of deeply held cultural beliefs. Examples of common metanarratives in the Russian discourse space include:

- Moscow as the Third Rome, which defines a unique "messianic role" for Russia in world history (Duncan, 2002);

- Russia as a 'besieged fortress,' under constant threat from outside enemies that are determined to use Russia as a scapegoat in the event of world crisis, creating a constant sense of crisis among citizens and an identity of eternal victimhood (Yablokov, 2018);

- Russia as the center of the Slavic universe (Suslov, 2012);

- Russia, as the torchbearer of "an anti-liberal Europe" (Laruelle, 2000);

- The collective West as a conspiratorial and insidious "Other," depicting the West as a collective entity that is ambiguously conspiring to "undermine the progress of the Russian nation towards its glorious future" (Yablokov, 2018);

- The Kremlin as a global underdog, positioning according to the ideas of populist theory of power (Yablokov, 2015);

- The uniqueness of Russia and of the Russian soul (русская душа), with a unique destiny to bridge Europe and Asia (Laruelle, 2012). 
Eurosodom: Specifics of Weaponized Sexuality and Gender-Based Narratives... | 135

By utilizing a similar narrative framework, we critically interpret the disinformation micro-stories that make up our sample. In the sample, we were able to detect seven distinct metanarratives defined by 25 narratives that vertically integrate to convey one singular message: that the West is a decaying power that has become ripe with immorality and sexual deviance because it has strayed from traditional, conservative values defined by the worldview of the Kremlin. The stories in our sample range thematically from targeting LGBTQ+ individuals in Western Europe, to NATO soldiers in Lithuania, to migrants from the Middle East in Europe. However, all of these seemingly unrelated stories vertically integrate to support the same worldview.

In order to analyze Russian and pro-Russian disinformation that focuses on sexuality and gender-based narratives published from 2015 to 2020, we have utilized the EU vs. Disinfo database, a project managed by the European External Action Service's East StratCom Task Force. ${ }^{1}$ To date, the database houses 8,820 disinformation cases in 31 languages, as well as disproofs for each story, similar to fact-checking. Because the sample for this analysis came from already disproven stories in the EU vs. Disinfo database, disproving the information was not an aspect of our analysis. In order to find suitable cases, we conducted relevant keyword searches within the database for stories published from January 2015 to March 2020. The relevant keywords related to specifics of sexuality and gender-based narratives include:

- European values

- Moral decay

- Moral decline

- Gayropa

- Western values

- Family values

- EU disintegration

- Chaos 


\section{MONOGRAPH}

- Anglo-saxon

- Christianity/Christian values

- Migrant

- Sexual assault/sexual violence

- Semi-men

- LGBT/LGBTQ

Because of the relatively niche content matter and the design of the disinformation micro-stories in our sample, the geographic scope of this investigation is broad. The analysis of the collected sample was performed by a two-fold process. First, we operationalized the concepts in the disinformation micro-stories contained in our sample by conducting a quantitative analysis of certain characteristics in the sample. This coding schema includes the following elements:

- Date of Publication

- Metanarrative detected

- Narrative detected

- Primary Motivation

- Secondary Motivation

- Target Audience

- Language

- Primary Institutional-Level Target

- Secondary Institutional-Level Target

- Primary Country-Level Target

- Secondary Country-Level Target

- Primary Individual Target

- Secondary Individual Target

- Source of Authority 
Eurosodom: Specifics of Weaponized Sexuality and Gender-Based Narratives... | 137

Secondly, we analyzed the actual content of the narratives in our sample through the lenses of the theoretical frameworks described above. In order to scrutinize the content of the most common narratives present in our collected sample, we deconstructed each story and sorted them based on the presence of certain characteristics. This methodology is based on the model presented by Bernardi et al. (2012). As a result, seven broad metanarratives and 25 specific narratives were present in our collected sample. See table 1 below:

\begin{tabular}{|c|c|c|}
\hline \multicolumn{2}{|r|}{ Broad metanarratives } & Specific narratives \\
\hline 1 & $\begin{array}{l}\text { Western perversion of traditional } \\
\text { morals and resulting collapse }\end{array}$ & $\begin{array}{l}\text { - Collapse of traditional values in the West } \\
\text { - Abandonment of Christianity in the West } \\
\text { - Extreme sexual deviance in the West } \\
\text { - Extreme adolescent empowerment } \\
\text { - The disintegration of the family unit in the West }\end{array}$ \\
\hline 2 & $\begin{array}{l}\text { Disintegration of Traditional } \\
\text { Gender Roles in the West }\end{array}$ & $\begin{array}{l}\text { - The rise of "semi-men" in Europe } \\
\text { - Rising imperial "gay dictatorship" in Europe } \\
\text { - There exist no gender differences in the West } \\
\text { - Women are masculinized in the West } \\
\text { - Dictatorial feminism }\end{array}$ \\
\hline 3 & $\begin{array}{l}\text { Western subversion via "gender- } \\
\text { based ideology" }\end{array}$ & $\begin{array}{l}\text { - Homosexuality is forced by Western on the Russian } \\
\text { sphere of influence } \\
\text { - Weaponization of "gender-based ideology" by } \\
\text { non-governmental organizations and philanthropic } \\
\text { individuals } \\
\text { - Weaponization of "gender-based ideology" by gover- } \\
\text { nmental institutions } \\
\text { - Legal enforcement of "gender-based ideology" by } \\
\text { international institutions } \\
\text { - Western \& LGBTQ+ plus funding of pro-Western oppo- } \\
\text { sition groups in Russia and Eastern Europe }\end{array}$ \\
\hline 4 & $\begin{array}{l}\text { Russia as the savior of traditio- } \\
\text { nal Christendom }\end{array}$ & $\begin{array}{l}\text { - Russia as the savior of traditional, Christian values } \\
\text { as Europe flails }\end{array}$ \\
\hline 5 & Sexual predation by an '0ther' & $\begin{array}{l}\text { - Muslim men as perpetrators of sexual violence in the } \\
\text { EU } \\
\text { - Ukrainian men as perpetrators of sexual violence } \\
\text { - NATO servicemembers are perpetrators of sexual } \\
\text { violence } \\
\text { - Jewish men as perpetrators of sexual violence }\end{array}$ \\
\hline
\end{tabular}




\section{MONOGRAPH}

\begin{tabular}{|c|l|l|}
\hline \multicolumn{2}{|c|}{ Broad metanarratives } & \multicolumn{1}{c|}{ Specific narratives } \\
\hline 6 & $\begin{array}{l}\text { Complicity of western elites, } \\
\text { media, and judicial systems }\end{array}$ & $\begin{array}{l}\text { - Impunity in western judicial systems for sexual and } \\
\text { gender-based violence committed by Muslim men } \\
\text { Willful Western media blindness to sexual and } \\
\text { gender-based violence committed by Muslim men } \\
\text { Western elites and governments disregard sexual and } \\
\text { gender-based violence committed by Muslim men }\end{array}$ \\
\hline 7 & Extreme tolerance in the West & $\begin{array}{l}\text { - Extreme levels of tolerance in the West as a result of } \\
\text { a skewed understanding of reality }\end{array}$ \\
\hline
\end{tabular}

Table 1: Broad metanarratives and specific narratives.

Although these categories are non-exhaustive and relatively subjective, each metanarrative and narrative are defined by the presence of specific characteristics. These categories are explained in detail in the next section.

\section{Results and discussion}

In our sample of $\mathrm{N}=185$ analyzed stories, seven metanarratives emerged as the most prevalent themes. These seven metanarratives can be categorized into two even broader categories. The first contains the stories that allege a collapse of traditional religious, family, and gender values in the West. This theme contains four broad metanarratives shown in Table 1 (i.e. 1-4). The second category is centered upon alleged sexual violence in European countries and the reactions of those states' governments, media, police, judiciary, and citizens and contains three broad metanarratives shown in Table 1 (i.e. 5-7). This list of metanarratives is not exhaustive, and each metanarrative contains several rumor families that describe similar events or events with the same antecedent. However, they can fit into different rumor mosaics depending on the focus of the story. Each narrative vertically integrates to support one another, meaning that their boundaries are somewhat fluid. However, each metanarrative is distinct and is defined by certain characteristics that are described below. All of the metanarratives are meant to convey an ultimate message: that the West, led by the EU and Western military institutions, brings moral perversion in the form of violence and sexual vices to populations that embrace the principles of liberalism, tolerance, and multiculturalism. 


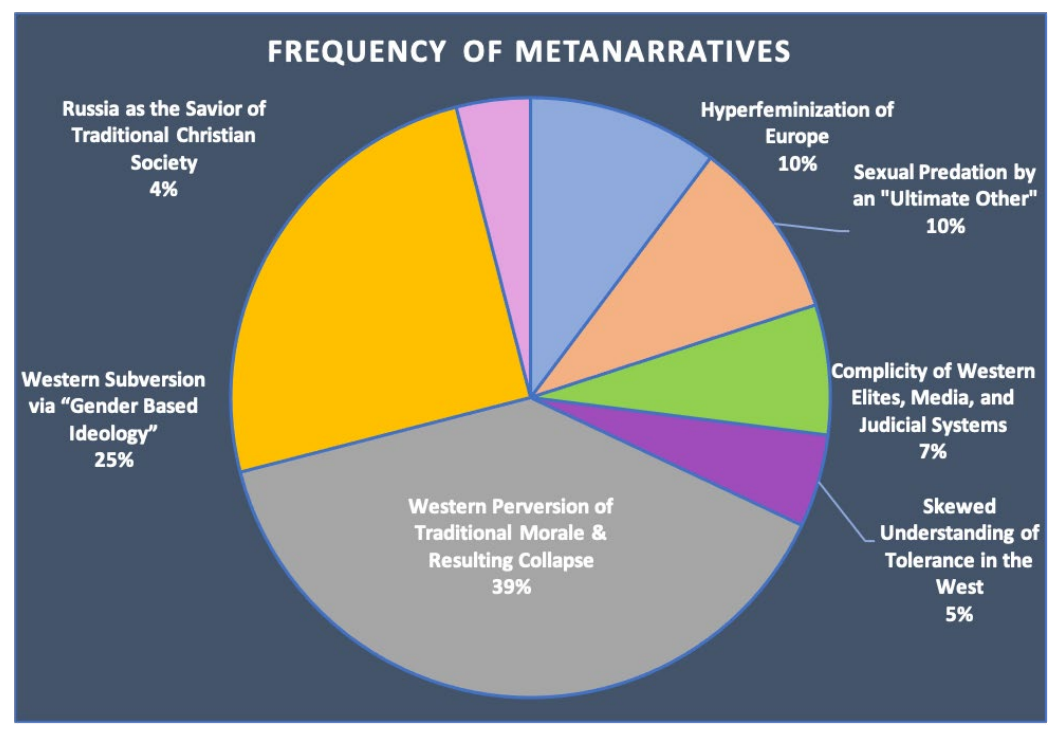

Figure 1: Frequency of metanarrative distribution.

\subsection{Western Perversion of Traditional Morals and Resulting Collapse}

In 2013, Putin spoke at the Valdai Discussion Club, a forum that "aims to promote dialogue of Russian and international intellectual elites" as an alternative to Western platforms, stating that "the Euro-Atlantic countries were rejecting their roots, including Christian values that constitute the basis of Western civilization" (Rutland, 2014). Consistent with this message, disinformation stories from this metanarrative center around these depictions of purportedly declining European societies due to an abandonment of traditional cultural and religious order. Stories include broad accusations of an abandonment of traditional values and of decay in morality, of a rejection of the family unit, to allegations of sexual deviancy, with descriptions of the legalization of bestiality and pedophilia, as well as hypersexualization in the West (Article $1 ; 2 ; 3 ; 4 ; 7$ ). In addition, there are descriptions of the material decadence of the West, including descriptions of Westerners as "worshipping money," "amorphous consumers," and as a "cult of freedom at any cost" (Article 5; 6). Finally, this metanarrative contains stories that focus on the abandonment of Christianity in Europe. Prevalent in this metanarrative are stories 
that focus on the West's, and especially of the European Union's, "abandonment of Christianity" (Article 8). These kinds of stories include rumors of marginalization of Christians in European Union policy, a genocide of Christians in Europe, and conspiracy theories about Europe's increasing distance from Christianity causing the fire at Notre Dame (Article $9 ; 10 ; 11 ; 12 ; 13 ; 14$ ).

\subsection{Disintegration of Traditional Gender Norms in the West}

Since Putin's return to power in 2012, the gender dimension has been one of the most significant aspects of allegations directed at the West by the Kremlin (Riabov \& Riabova, 2019). This segment expands on the now well-known "gayropa" trope that was created and utilized by Russian authorities as a kind of cognitive device. This term has become a "catchall" in Russian media for the what the Kremlin sees as an abandonment of traditional gender and sexual norms, as well as a representation of the decline in relations between Russia and the West since the annexation of Crimea (Foxhall, 2017). This definition expands on the classic understanding of 'gayropa' by focusing on all stories that allege a "feminization" of European society. A prominent theme in this metanarrative is the feminization, clearly used a synonym for "weakening," of European men, who are oft referred to as "semi-men" in Kremlin-sponsored disinformation (Article 15). The implication of the claim of "semi-men" is that European men are unable to fulfill their gender duty in protecting European women from "foreign invaders," often the imagery that the Kremlin utilizes when describing Muslim refugees in the EU (Article 16). In addition, the feminization of men is portrayed in tandem with the purported "masculinization of women" in the West (Article 17). Often, these stories would target "post-modern feminism" as being synonymous with the "destruction of men" (Article 18). Alternatively, many stories allege that there are "no gender differences" in the West, as radical liberalism and feminism have made it "illegal" to acknowledge differences between genders (Article 19).

Additionally, this metanarrative contains stories that claim a "gay dictatorship" seeks world domination and that "gay fascism" is the ideology of Europe (Article $20 ; 21)$. Similarly, many stories targeted the first openly gay high-level politicians of several countries, including Serbia, the United States, and Luxembourg, among 
Eurosodom: Specifics of Weaponized Sexuality and Gender-Based Narratives... | 141

MONOGRAPH

others, as well as female leaders from numerous European and Central Asian countries and the United States. These stories are meant to implicate the West, and especially Europe, in the disintegration of traditional gender norms and as engaging in dangerous transgressions of gender boundaries. On the other hand, Russia and state leadership are depicted as a bastion of real women and real men and a protector of the traditional gender order.

\subsection{Western Subversion via 'Gender Based Ideology'}

As Putin embraces traditional, conservative values since his return to the presidency in 2012, he has also crafted a narrative that warns of the exportation of this liberal, Western model to Russia and the near abroad. With this narrative, Putin creates a rationale for aggressively anti-Western, anti-liberal cultural growth, and positions Russia as constantly in danger of falling subject to this immoral order. Therefore, this narrative family includes descriptions of forced homosexuality by Western and international powers. This force occurs through both hidden subversion and legal mechanisms and descriptions of an enforcement of a "liberal gender order" through "radical feminism and gender theories" by Western powers, powerful philanthropic donors and non-governmental organizations, and international institutions (Article 22).

The most prominent narrative within this metanarrative is the weaponization of gender-based ideology by Western powers and international institutions, predominately the United Nations. Here, a large conspiracy theory also reigns, that claims that the world's "liberal-globalist elites" are attempting to dominate the world to implement a "liberal gender order," often described as being under the leadership of George Soros and the Clintons (Article 23). According to the Kremlin and its allies, Western powers attempt coups and bring down governments by weaponizing "gender ideologies" and feminism in countries that are not aligned with the liberal West (Article 24). In our sample, this narrative was highly targeted towards post-Soviet states in the South Caucasus, especially Georgia and Armenia. Stories alleged that the "Soros Army" sends "Soros spies" to Armenia to force them to ratify the Istanbul Convention, which they claimed sought to undermine Russo-Armenian relations to force Armenia to become the "Netherlands of the South 
MONOGRAPH

Caucasus" (Article 25). In Georgia, the storyline followed that Soros and the 0pen Society Foundation meant to disrupt the "traditional gender order" in Georgia, which would cause an eruption of violence (Article 28).

Stories alleging forced homosexuality in Europe, in which the European Union forces potential member states to "propagate" or celebrate homosexuality, were also common in the sample. Often, these stories center upon international institutions, such as NATO and the UN, forcing countries to legalize same-sex marriage before gaining membership. One story in the sample claimed that NATO General Secretary Jens Stoltenberg was going to force Georgia to recognize gay marriage in order to become a member of NATO (Article 29). These stories also largely target countries in what Russia considers its near abroad, furthering Kremlin interests in dissuading these countries from seeking membership in Western-led international institutions. Another variation of this story claimed that Belarus was being punished by the EU, usually through large Schengen Visa fees, for not having a large enough LGBTQ+ community (Article 30).

\subsection{Sexual Predation by an 'Other'}

Stories within this metanarrative depict an 'Other' engaged in sexual violence, usually against ethnically Russian or Russian-allied women, and as purveyors of immorality in Europe. All of the stories in this metanarrative consist of a common storyline filled with familiar archetypes: a hero in the form of the Russian government, a villain in the form of an "Ultimate 0ther," a victim in the form of an ethnically Russian or pro-Russian helpless woman, a non-responsive bystander, a witness, and a complicit police force and state apparatus. This metanarrative has four distinct narratives, classified by types of "Ultimate 0ther" that are targeted: 1) NATO troops, 2) Islamic men in the EU, 3) Ukrainian men, and 4) Jewish men.

\subsection{Muslim Migrants as the Ultimate Other}

In 2015, at the height of the European migrant crisis, the Kremlin exploited the political situation in Europe as European citizens and the international community became dissatisfied with European governments' and the EU's handling of the 
Eurosodom: Specifics of Weaponized Sexuality and Gender-Based Narratives... | 143

influx of refugees from the Middle East. The Kremlin used the events as evidence that multiculturalism in Europe was failing, that accepting refugees from Muslim-majority countries led to the collapse of 'law and order', and that the EU was plagued by inefficiency and "extreme tolerance" (Article 31; 32). In this narrative family, Muslim men are represented as an "Ultimate 0ther," and are juxtaposed in the rumors with a witness of the events who is of Eastern or Central European origins living in Western Europe. This archetype is significant because their legitimacy is drawn from their national origins, while they maintain authority to discuss the West because of their place of residence.

The 2015-2016 New Year's Eve attacks in Cologne, Germany are central to this narrative. The Cologne attacks are a prime example of one of the Kremlin's most utilized disinformation tactics: manipulation of truth. On December 31, 2015, large-scale sexual assaults and burglaries were reported in several German towns. Over 1,200 criminal charges were made, approximately 500 of which pertained to sexual assault (DW, 2017). In this case, the Kremlin degraded the poignancy of the attacks that did occur and contributed to the lack of an appropriate response by dramatizing the events, perpetuating false narratives about subsequent sexual violence by Muslim men or the legal protection of attackers by European governments for years to come, and creating a kind of "censorship through noise" (Coppins, 2020). Following the 2015-2016 attacks, Russian and pro-Russian outlets have published stories that claim there to be high levels of sexual violence in EU member states, especially in Germany and Sweden, greatly overestimating those numbers (Article 35; 36; 37).

\subsection{Western Soldiers as the Ultimate Other}

The stories in this narrative family are nearly the same in substance and function as the stories of alleged sexual assault by Muslim migrants in Europe; however, the "Ultimate Other" in this case is a NATO soldier. Often, the soldier in these stories is Western European and the place of the attack is a former Soviet Republic or Eastern Bloc country. One example comes from Lithuania, where a story emerged that alleged that a German member of the NATO Enhanced Forward Presence stationed in Rukla had assaulted an underage Lithuanian girl (Article 33). Another is set in Ukraine, 
where Lithuanian NATO soldiers were accused of assaulting underage Ukrainian girls (Article 38). In another example, American NATO soldiers were rumored to be involved in a sex trafficking ring in the Romanian towns of Caracal and Deveselu (Article 39). In these stories, the implication is that if you are a member of NAT0 and have soldiers stationed on the ground, they bring violence and moral degradation.

\subsection{Complicity of Western Elites, Media, and Judicial Systems}

The stories in this metanarrative allege that Western elites, media, and judicial systems are unwilling or unable to address sexual and gender-based violence in Europe when those crimes are committed by a Muslim man, especially with refugee status. It contains stories that range from alleged judicial changes in Western Europe, to leaders who refuse to denounce sexual or gender-based violence if the perpetrators are immigrants, to Western media that actively covers up and refuses to report on sexual violence in Europe. These narratives primarily target Germany and Sweden, as well as the European Union as an institution. The most prevalent storyline in this metanarrative alleges that legal impunity has been granted for Muslim men who commit sexual violence in Europe. In one such story, it was claimed that a new law was passed in Germany that made it illegal to prosecute someone of sexual assault if they were a refugee. In fact, after the 2015-2016 NYE Cologne Attacks, the German Parliament passed a stricter sexual assault law (Connely, 2016).

However, this focus attempts to implicate Western governments and individual leaders, especially German Chancellor Angela Merkel, in the crimes themselves and to allege that liberal governments are unwilling to protect their own citizens. Another story in the sample claimed that "not a single criminal case has been opened in Germany" for more than 500 sexual assault cases perpetrated by refugees (Article 40). In a similar vein, another story claimed that the "Feminist Government of Sweden" ordered police not to investigate sexual violence when the attack was committed by a refugee (Article 41). In addition, this metanarrative contains rumors that protests against sexual violence were shut down in Germany, alleging a crackdown on free speech and a national cover-up of sexual and gender-based violence in the country (Article 41). 
Eurosodom: Specifics of Weaponized Sexuality and Gender-Based Narratives... | 145

MONOGRAPH

\subsection{Radical Tolerance in the West}

This narrative family contains stories that allege that European society and governments are so "radically tolerant" that they allow failed multiculturalism and violence to destroy their countries. In his annual address on December 12, 2013, Vladimir Putin 'lambasted 'so-called tolerance' as 'sexless and infertile' and fundamentally unnecessary for Russia with its great history and culture" (Eksi \& Wood, 2019). He finished by advocating an adherence to conservative values as a defense against "moving backward and down toward chaotic darkness" (Eksi \& Wood, 2019). This metanarrative is defined by this focus on so-called "radical tolerance" in the West, often portrayed as leading to a collapse due to the inefficacy of multiculturalism. Clearly, this serves as a defense for the Kremlin to not adhere to a goal of liberal multiculturalism. In many of the stories in this metanarrative, the sexual assault and other violence in Europe is blamed on the West's misguided embrace of "tolerance."

With headlines such as "Tolerant Sweden Fed Up with Migrants," several rumors in our sample described the way that radical tolerance has caused European countries, most commonly targeting Scandinavian countries and Germany, to accept sexual violence and an overall moral depravity, despite the grievances from their citizens (Article 42). One of the most striking storylines in this metanarrative alleged that victims of sexual assault in Europe are forced to apologize to their assailants (Article 41). Other stories in our sample took another direction with a criticism of 'radical tolerance,' claiming that European states had become so concerned about political correctness that they have passed laws requiring all parties to sign a "contract of consent" before engaging in any sort of sexual activity or the man could be charged with assault (Article 41). Additionally, other stories claim that it is illegal for men to "even think about women" in Europe, as heterosexual white men have become "villains" in the West (Article 45).

\subsection{Russia as the Savior of Traditional Christendom and "True Europe"}

In his annual address to the Federal Assembly in 2013, Putin "went 'global' with his moral agenda," criticizing the West's abandonment of morality and posi- 
tioning Russia as a "guardian of traditional values worldwide" (Sharafutidinova, 2014). The stories within this metanarrative align with this self-prescribed status for Russia as the savior of traditional society. This metanarrative includes stories that, while also focusing on the decaying and failing West, center upon a kind of messianic role of the Russian Federation under the rule of Vladimir Putin. Some of these narratives explicitly state that the Russian political and cultural system is "one to be sought," in contrast to "dangerous Western 'liberal democracy,' that... puts all efforts in degrading and discrediting traditional values" (Article 46). Another variation alleged that Russia was the "global protector of free speech" as the West continues to "censor" non-liberal voices (Article 47). Other stories described Vladimir Putin himself as the savior of the Russian state, as the only guard against Russia falling for the "trap of hedonistic liberalism" (Article 48). The most prevalent story in this metanarrative focused on the image of Russia as a savior of Christendom, as the "preserve[r] of the original Christian spirit" (Article 49). In this same theme, stories alleged that religious leaders from around the world, but mostly Slavic countries, believed Putin to be the only man who could defend the Christian world from the dangers that liberal modernity poses (Article 50).

\section{Conclusion}

Russian and pro-Russian disinformation outlets utilize sexuality and gender-based narratives in disinformation operations because of their extremely potent emotionally based content and their ability to reuse storylines and narratives in different cultural contexts with only minor corrections. Sexuality and gender-based narratives are cheap and effective cognitive weapons in the Kremlin's propaganda and "fellow travelers'" toolkit that can be used equally abroad and at home. From this analysis, it emerges that the Kremlin has a perennial cast of characters and villains, which can be shifted and modified depending on the targeted national audience. Taken in their totality, all of these metanarratives and sub-narratives create a unified message. Namely, that Western governance systems, and in particular their values of multiculturalism and tolerance, will lead to moral perversion and deviance, especially in the way of sexual vices and a corruption of 'traditional' femininity and masculinity. Here, "the Collective West" presents dual physical and spiritual threats via merging of all possible transgressions of Russian traditional cultural boundaries. Our analysis 
Eurosodom: Specifics of Weaponized Sexuality and Gender-Based Narratives... | 147

MONOGRAPH

has demonstrated that disinformation containing sexuality and gender-based narratives is an effective means of modifying cognition and behavior in a variety of segments of targeted populations. Importantly, these themes are very stable, perennial themes which can be exploited through time and across cultures with lasting effects as they rely on a specific set of heuristics. As we have demonstrated, these kinds of narratives require specific attention, systematic monitoring, and future research due to their direct impact on national levels of cognitive resilience in targeted populations. Despite analyzing a large sample from a five year period of time, we were not able to systematically analyze the diffusion and proliferation of these stories outside of the EU vs. Disinfo database and their "mutations" as they are dynamically transmitted across various online platforms and websites. Future direction of study should address the ways that sexuality and gender-based narratives are modified for different audiences based on national cultural specifics of targeted populations. We are convinced that our results possess significant relevance for national security planners and practitioners at national and EU-wide levels.

\section{References}

Avramov, K., Cushman, E. (2019). Weaponization of Metaphors in Russian Propaganda: Sexual Violence, as State Sovereignty Violation. Small Wars Journal, 2019.

Bauer, R. A., \& Gleicher, D. B. (1953). Word-of-mouth communication in the Soviet Union. Public Opinion Quarterly, 17(3), 297-310.

Bernardi, D. L., Cheong, P. H., Lundry, C., \& Ruston, S. W. (2012). Narrative landmines: Rumors, Islamist extremism, and the struggle for strategic influence. Rutgers University Press.

Betz, D. (2008). The virtual dimension of contemporary insurgency and counterinsurgency. Small wars \& insurgencies, 19(4), 510-540.

Cheskin, A. (2017). Russian soft power in Ukraine: A structural perspective. Communist and Post-Communist Studies, 50(4), 277-287.

Cohn, C. (1993). Wars, Wimps and Women. Miriam Cooke and Angela Woollacott. Connely, K. (2016). “Germany toughens rape laws after New Year's Eve attacks in Cologne," The Guardian, https://www.theguardian.com/world/2016/jul/07/ german-mps-back-stricter-rape-laws-after-cologne-attacks. 
Coppins, M. (2020). "The Billion Dollar Disinformation Campaign to Reelect the President," The Atlantic, https://www.theatlantic.com/magazine/ archive/2020/03/the-2020-disinformation-war/605530/.

Deutsche Welle (2017). “Report: Cologne New Year's Eve attacks 'could have been prevented,' DW, https://www.dw.com/en/report-cologne-new-years-eveattacks-could-have-been-prevented/a-37979296

DiFonzo, N., \& Bordia, P. (2007). Rumor psychology: Social and organizational approaches. American Psychological Association.

Duncan, P. J. (2002). Russian messianism: third Rome, revolution, communism and after. Routledge.

Eksi, B., \& Wood, E. A. (2019). Right-wing populism as gendered performance: Janus-faced masculinity in the leadership of Vladimir Putin and Recep T. Erdogan. Theory and Society, 48(5), 733-751.

EU vs. Disinfo, (2020). "About," https://euvsdisinfo.eu/about/

Fierstein, H. (2013). “Russia's Anti-Gay Crackdown," New York Times, https://www. nytimes.com/2013/07/22/opinion/russias-anti-gay-crackdown.html.

Fine, G. A., \& Heath, C. (Eds.). (2009). Rumor mills: The social impact of rumor and legend. Transaction Publishers.

Fiske, S. T. (2018). Social beings: Core motives in social psychology. John Wiley \& Sons. Foxall, A. (2013). Photographing Vladimir Putin: Masculinity, nationalism and visuality in Russian political culture. Geopolitics, 18(1), 132-156.

Foxall, A. (2019). From Evropa to Gayropa: A critical geopolitics of the European Union as seen from Russia. Geopolitics, 24(1), 174-193.

Gessen, M. (2013). The man without a face: The unlikely rise of Vladimir Putin. Riverhead Books

Gourley, Seran, (2020) "To fight disinformation, we need to weaponize the truth, Wired, 2020, https://www.wired.co.uk/article/fix-disinformation-facts

Kahneman, D. (2011). Thinking, fast and slow. Macmillan.

Laruelle, M. (2000). Russia as an anti-liberal European civilisation. The new Russian nationalism: imperialism, ethnicity and authoritarianism, 2015, 275-297.

Laruelle, M. (2012). Larger, higher, farther north... geographical metanarratives of the nation in Russia. Eurasian Geography and Economics, 53(5), 557-574.

McCauley, K. N. (2016). Russian Influence Campaigns against the West: From the Cold War to Putin. CreateSpace Independent Publishing Platform. 
Eurosodom: Specifics of Weaponized Sexuality and Gender-Based Narratives... | 149

MONOGRAPH

Novitskaya, A. (2017). Patriotism, sentiment, and male hysteria: Putin's masculinity politics and the persecution of non-heterosexual Russians. Norma, 12(3-4), 302-318. RFE/RL, (2018), “'A Living Hell': Russia's 'Propaganda' Law Damaging LGBT Youth, HRW Finds," Radio Free Europe/Radio Liberty, https://www.rferl.org/a/russiagay-propaganda-law-rights/29651416.html.

Riabov, 0., \& Riabova, T. (2014). The remasculinization of Russia? Gender, nationalism, and the legitimation of power under Vladimir Putin. Problems of Post-communism, 61(2), 23-35.

Riabova, T., \& Riabov, 0. (2019). The "Rape of Europe": 2016 New Year's Eve sexual assaults in Cologne in hegemonic discourse of Russian media. Communist and Post-Communist Studies, 52(2), 145-154.

Rutland, P. (2014). The Pussy Riot affair: gender and national identity in Putin's Russia. Nationalities Papers, 42(4), 575-582.

Sharafutdinova, G. (2014). The Pussy Riot affair and Putin's démarche from sovereign democracy to sovereign morality. Nationalities Papers, 42(4), 615-621.

Shibutani, T. (1966). Improvised news: A sociological study of rumor. Ardent Media. Snyder, T. (2018). The Road to Unfreedom: Russia, Europe, America. Tim Duggan Books. Sperling, V. (2015). Sex, politics, and Putin: Political legitimacy in Russia. 0xford University Press.

Sunstein, C. R. (2002). Risk and reason: Safety, law, and the environment. Cambridge University Press.

Suslov, M. (2012). Geographical metanarratives in Russia and the european east: contemporary pan-Slavism. Eurasian Geography and Economics, 53(5), 575-595.

Turner, R. H., \& Killian, L. M. (1957). Collective behavior (Vol. 3). Englewood Cliffs, NJ: Prentice-Hall.

Van Dijk, T. (1995). Discourse Analysis as Ideology Analysis,[w:] Language and Peace, ed. C. Schäffner, A. Wenden.

Yablokov, I. (2018). Fortress Russia: Conspiracy theories in the post-Soviet world. John Wiley \& Sons.

\section{Notes}

[1] Although we have relied on the EU vs. Disinfo database, we have several reservations regarding the means of collection, classification, and disproval process of stories included in the database. In particular, too many opinion pieces or blog posts are classified as disinforma- 
MONOGRAPH

tion and are presented as news. In addition, outlets are all treated as pro-Kremlin, or Kremlin sponsored outlets, without serious discussion as to their independence. We have tried to avoid including opinion pieces in the sample collected from the database. Despite these critiques, the EU vs. Disinfo database was a useful source for the purpose of this analysis.

\section{Appendix 1: Primary Articles Cited (from the sam- ple analyzed)}

Article 1: Geopolitica, “Il Ruolo Dell'Europa Nel Nuovo Ordine Multipolare," 2020, https:// www.geopolitica.ru/it/article/il-ruolo-delleuropa-nel-nuovo-ordine-multipolare

Article 2: Kramola, “Процесс разрушения морали и семьи в Европе, 2018, https:// www.kramola.info/vesti/vlast/process-razrusheniya-morali-i-semi-v-evrope

Article 3: REN TV, “Общество педофилов готовится выйти на политическую арену в Нидерландах, 2019, https://ren.tv/news/v-mire/639955-obshchestvo-pedofilovgotovitsia-vyiti-na-politicheskuiu-arenu-v-niderlandakh.

Article 4: Zavtra, “Педофилы рвутся в политику: "речь идёт о захвате власти," 2019, http://zavtra.ru/events/pedofili rvutsya $\mathrm{v}$ politiku rech idyot o zahvate vlasti ;

Article 5: Geopolitica, “Stati Canaglia, Nazioni Sovrane, 2020, https://www.geopolitica. $\mathrm{ru}$ /it/article/stati-canaglia-nazioni-sovrane.

Article 6: Geopolitica, "La Nuovo Arte Della Guerra: Conflitti 2.0," 2020, https://www. geopolitica.ru/it/article/la-nuova-arte-della-guerra-conflitti-20

Article 7: Eurasianet, "Russia: The Clash of Civilization Comes to Valdai Club," 2016, https://eurasianet.org/russia-clash-civilizations-comes-valdai-club

Article 8: Нам Гомель, «Западная Европа отказывается от хуристианских корней,» 2019, https://sozh.info/zapadnaya-evropa-otkazyvaetsya-ot-khristianskikh-kornejj/

Article9:SputnikNews, "AvocatulPeterCostea:ParlamentulEuropeanatacămișcareapro-familie din România," 2020, https://ro.sputnik.md/International/20200114/28854021/ Parlamentul-European-ataca-miscarea-pro-familie-din-Romania.html

Article 10: RT, "Crosstalk on Christianity: Forgotten Persecution," 2019, https://www. rt.com/shows/crosstalk/458967-china-christians-persecution-highlights/

Article 11: Media Monitoring, 2017, http://mediamonitoring.ge/mms/includes/image. php?id=6028631\&name=22.04.2019-\%E1\%83\%90\%E1\%83\%A1\%E1\%83\%90\%E1\%8 3\%95\%E1\%83\%90\%E1\%83\%9A-\%E1\%83\%93\%E1\%83\%90\%E1\%83\%A1\%E1\%83\%90 \%E1\%83\%95\%E1\%83\%90\%E1\%83\%9A\%E1\%83\%98\&p=1\&lang=Ge 
Eurosodom: Specifics of Weaponized Sexuality and Gender-Based Narratives... | 151

MONOGRAPH

Article 12: Sputnik News, "Notre Dame: Francuzi płacza, Polacy szikaja spisku," 2019, https://pl.sputniknews.com/opinie/2019041710227717-notre-dame-francuziplacza-polacy-szukaja-spisku-sputnik/

Article 13: Sputnik News, “Kod Da vinci rozwikłany: pożar w Notre Dame punktem wyjścia dla apokalipsy," 2019, https://pl.sputniknews.com/swiat/2019042310264895-kodda-Vinci-rozwiklany-pozar-w-notre-dame-punktem-wyjscia-dla-apokalipsy-sputnik/

Article 14: Sputnik News, "Notre-Dame: Zamiast katoliskiej iglisy muzułmański minaret," 2019, https://pl.sputniknews.com/swiat/2019051710411198-Sputnik-notre-damezamiast-katolickiej-iglicy-muzulmanski-minaret/

Article 15: Geopolitica, "Introduzione A Noomachia. Lezione 10: La Noomachia nel XXI Secolo," 2019, https://www.geopolitica.ru/it/article/introduzione-noomachia-lezione10-la-noomachia-nel-xxi-secolo.

Article 16: News Front, "Europe Commits Suicide by Importing Barbarians - Russia Watches With Great Sadness," 2019, https://en.news-front.info/2019/06/19/europe-commitssuicide-by-importing-barbarians-russia-watches-with-great-sadness/

Article 17: Geopolitica, “Una societa avvelenata?” 2019, https://www.geopolitica.ru/it/ article/una-societa-avvelenata ;

Article 18: Geopolitica, "Introduzione A Noomachia. Lezione 10. La Noomachia Nel XXI Secolo," 2019, https://www.geopolitica.ru/it/article/introduzione-noomachia-lezione10-la-noomachia-nel-xxi-secolo.

Article 19: Geopolitica, “Un Necrologio Del Mondo 0ccidentale," 2019, https://www. geopolitica.ru/it/article/un-necrologio-del-mondo-occidentale

Article 20: Cocoon, https://www.cocoon.ro/bizara-impunere-in-forta-a-homosexualilordictatura-gay-s-a-instituit-deja-in-uniunea-europeana/.

Article 21: Teleskop, “Представители британского посольства в Минске со своим ЛГБТ флагом ведут себя, как колонизаторы в колонии," 2019, http://teleskopby.org/2019/05/28/predstaviteli-britanskogo-posolstva-v-minske-so-svoim-lgbtflagom-vedut-sebya-kak-kolonizatory-v-kolonii/

Article 22: Geopolitica, “Il Militarismo Femminista Come Faccia Della Politica Occidentale," 2019, https:/www.geopolitica.ru/it/article/il-militarismo-femminista-come-facciadella-politica-occidentale

Article 23: Geopolitica, “La Metafisica Del Populismo,” 2019, https://www.geopolitica.

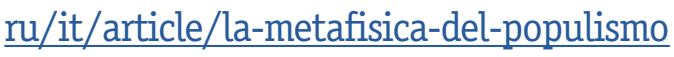


Article 24: Geopolitica, “La Nuova Arte Della Guerra: Conflitti 2.0," https://www. geopolitica.ru/it/article/la-nuova-arte-della-guerra-conflitti-20

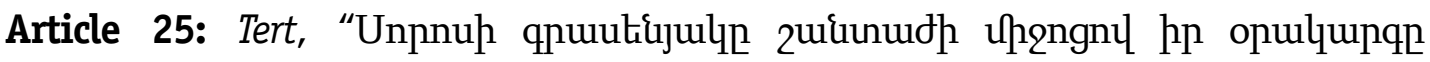

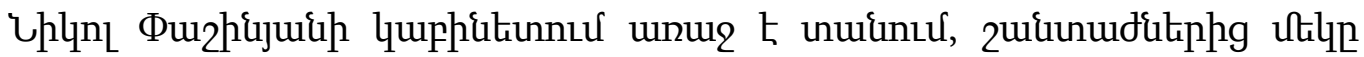

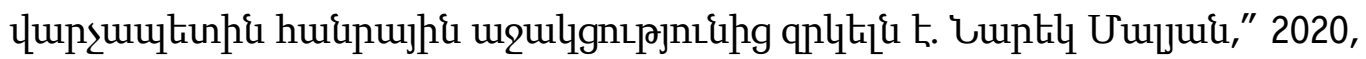
https://www.tert.am/am/news/2020/01/04/malyan/3178691 ;

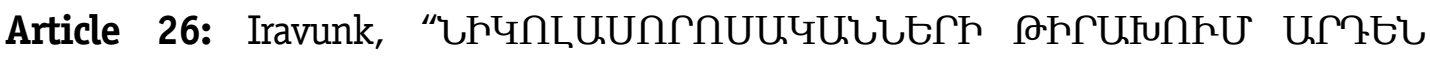
U3FFEしUГUしし E," 2019, https://www.iravunk.com/news/101286

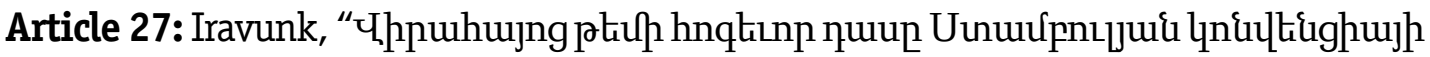

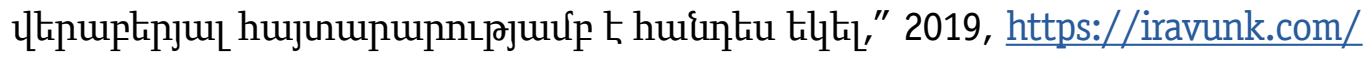
news/97854

Article 28: Strategic Culture Foundation, "Violence Erupts as West Turns its Sexual Subversion Weapon on Georgia," 2019, https://www.strategic-culture.org/news/2019/06/22/ violence-erupts-as-west-turns-its-sexual-subversion-weapon-on-georgia/.

Article 29: Marshall Press, “ https://marshalpress.ge/archives/261920

Article 30:Поднепровье Инфоо, «НадеждыБелорусской оппозиции,» 2019, https://web. archive.org/web/20190409111652/http://podneprovie-info.com/2019/04/08/ zavist-oppozicii/

Article 31: Hoвые Известия, «В Европе стартовал Флешмоб, в котором изнасилованные европейки извиняются перед мигрантами,» https://newizv.ru/ news/world/03-02-2018/v-evrope-startoval-fleshmob-v-kotorom-iznasilovannyeevropeyki-izvinyayutsya-pered-migrantami;

Article 32: Riafan, “Конец шведской идиллии: мигранты убивают и насилуют, пока СМИ врут про толерантность," 2016, https://riafan.ru/578751-konec-shvedskoiidillii-migranty-ubivayut-i-nasiluyut-poka-smi-vrut-pro-tolerantnost

Article 33: Viliaus politikos analizes institutas, “Lisa's Case Repeated: German Soldiers Accused of Rape," https://vilniusinstitute.lt/en/lisas-case-repeated-german-soldiersaccused-of-rape/

Article 34: Berlin-Hellersdorf, “Der Fall Lisa (13): Mann (23) wegen sexuellen Missbrauchs angeklagt," 2017, https://www.bz-berlin.de/berlin/marzahn-hellersdorf/der-falllisa-13-mann-23-wegen-sexuellen-missbrauchs-angeklagt

Article 35: Pravda, “Толерантную Швецию достали мигранты Читайте болыше, 2017, https://www.pravda.ru/society/1330434-efron sweden tolerance/. 
Eurosodom: Specifics of Weaponized Sexuality and Gender-Based Narratives... | 153

Article 36: Parlamenti Listy, "Německé soudy jsou zaplaveny kauzami "znásilněná uprchlíkem". Zde jsou ty nejděsivější, ale celkově je jich tolik, že si to nikdo nedovolí napsat," 2016, https://www.parlamentnilisty.cz/arena/monitor/Nemecke-soudyjsou-zaplaveny-kauzami-znasilnena-uprchlikem-Zde-jsou-ty-nejdesivejsi-alecelkove-je-jich-tolik-ze-si-to-nikdo-nedovoli-napsat-460342

Article 37: AC24, "Byla to obrovská legrace! Uvedl migrant, který společně s devatenácti partáky brutálně znásilnil třicetiletou ženu ve Švédsku," 2017, https://ac24.cz/ zpravy-ze-sveta/11648-obrovska-legrace-migrant-znasilnil-zenu-svedsko.

Article 38: Regnum, “В Донбассе наёмники изнасиловали двух девочек. ВСУ устроили самосуд," 2017, https://regnum.ru/news/polit/2323330.html.

Article 39: SputnikNews, “Presupusul criminal, suspect de trafic de persoane pentru soldații NAT0 de la Deveselu," 2019, https://ro.sputnik.md/society/20190727/27028039/ Presupusul-criminal-suspect-de-trafic-de-persoane-pentru-soldatii-NATO-dela-Deveselu.html?fbclid=IwAR3V2vzfEtl-M SpYzklzr33U 5IsnJ1Y4loJMFGL3w pb75ocUMHFqGRcA

Article 40: Aserialov, "Pravo Golosa Migranty delyat evropi vypusk," https://aserialov. net/pravo-golosa-migranty-delyat-evropu-vypusk-27-06-2018-tvc/

Article 41: Новости на Первом Канале, «Австрийский суд. Время покажет. Выпуск от 27.10.2016,» 2016, https://www.youtube.com/watch?v=hWOIZWfhapM

Article 42: $R T$, "Testing Tolerance, Swedes are saying 'enough' to immigrant no-go zones, sharia law \& gang rapes," 2018 https://rtd.rt.com/trailers/testing-tolerancesweden/.

Article 43: Новые Известия, «ВЕвропестартовал Флешмоб, в которомизнасилованные европейки извиняются перед мигрантами,» https://newizv.ru/news/world/0302-2018/v-evrope-startoval-fleshmob-v-kotorom-iznasilovannye-evropeykiizvinyayutsya-pered-migrantami

Article 44: Wayback Machine, “Секс-защита от беженцев: шведский вариант,» 2017, https:// web.archive.org/web/20180101195456/https://ria.ru/accents/20171225/1511689759. $\underline{\mathrm{html}}$

Article 45: Берестье News, “Иван Горбатенко: «Слабая женщина стабильности,» 2019, http://berestje-news.org/2019/02/18/ivan-gorbatenko-slabaya-zhenshhinapriznak-stabilnosti/. 
Article46:SputnikNews, “Юрьевосимпатии““правых”ЗападакРоссии:имблизкасистема ценностей," 2019, https://sputnik-abkhazia.ru/radio/20190522/1027424392/ Yurev-o-simpatii-pravykh-Zapada-k-Rossii-im-blizka-sistema-tsennostey.html

Article 47: РИА Новости, «Киселев назвал Россию чемпионом мира по свободе слова,» 2019, https://ria.ru/20190924/1559054887.html

Article 48: Geopolitica, "DISCORSO PER IL 40 ANNIVERSARIO DELLA RIVOLUZIONE IRANIANA (2020, KARAJ/ALBORZ)," 2020, https://www.geopolitica.ru/it/article/ discorso-il-40deg-anniversario-della-rivoluzione-iraniana-2020-karajalborz

Article 49: Нашь Гомель, «Западная Европа отказывается от христианских корней,» 2019, https://sozh.info/zapadnaya-evropa-otkazyvaetsya-ot-khristianskikh-kornejj/ Article 50: Sputnik News, "Pope Francis Sees Putin as "Only Man" to Defend Christians Around the World," 2016, https://sputniknews.com/politics/201602091034451116pope-francis-putin-christians/\#ixzz40BPMMk3F

\section{(c) $\underset{\mathrm{EY}}{(\mathbf{0}}$}

Este obra está bajo una licencia de Creative Commons Reconocimiento 4.0 Internacional. 